\section{To: (Receiving Organization) Distribution}

5. Proj./Prog./Dept./Div.:

DQO for TWRS Privatization

Phase 1: Tank Waste

Transfer Control/Waste

Management/TB\&P/Process

Engineering

\section{Originator Remarks:}

This document is being released into the supporting document system for retrievability purposes.

11. Receiver Remarks: 11A. Design Baseline Document? [] Yes $[X]$ No For release.
3. From: (Originating Organization) Technical Basis and Planning

6. Design Authority/ Design Agent/Cog. Engr.:

D. L. Banning
4. Related EDT No.:

$\mathrm{N} / \mathrm{A}$

7: Purchase Order No.:

$N / A$

9. Equip./Component No.:

$\mathrm{N} / \mathrm{A}$

10. System/Bldg./Facility: $\mathrm{N} / \mathrm{A}$

12. Major Assm. Dwg. No.: $N / A$

13. Permit/Permit Application No.: $\mathrm{N} / \mathrm{A}$

14. Required Response Date:

07/30/98

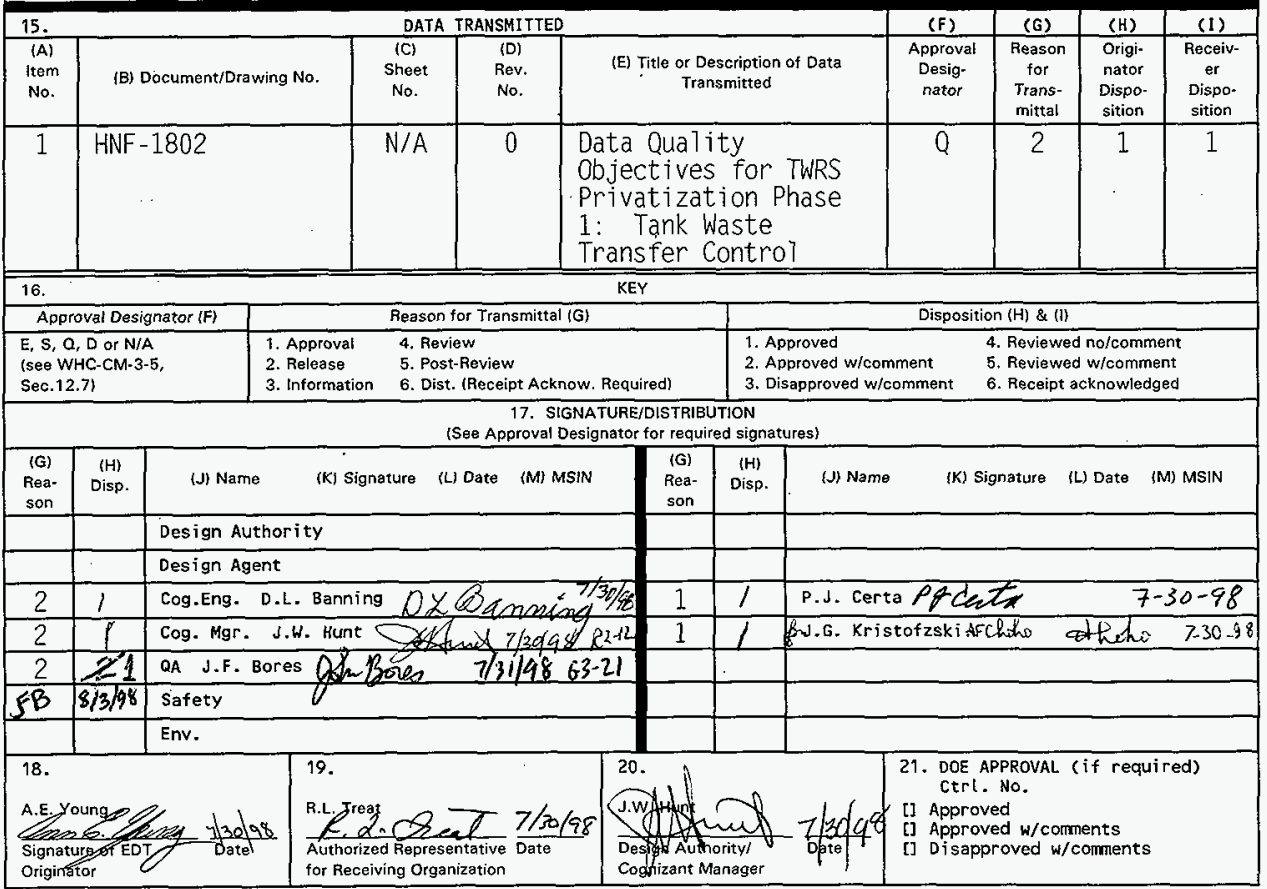

BD-7400-172-2(05/96) GEF097 


\title{
Data Quality Objectives for TWRS Privatization Phase 1: Tank Waste Transfer Control
}

\author{
D. L. Banning
}

Lockheed Martin Hanford. Corp., Richland, WA 99352

U.S. Department of Energy Contract DE-AC06-96RL13200

EDT/ECN: EDT-622458 UC: 2070

Org Code: 7A110 Charge Code: D223F

B\&R Code: EW 3120074 Total Pages: 30

Key Words: Data QuaTity Objectives, 000, TWRS, Privatization, Phase 1, Tank Waste Transfer Control, Tank Waste, Transfer Control, Transfer

Abstract: N/A

TRADEMARK DISCLAIMER. Reference herein to any specific commercial product, process, or service by trade name, trademark, manufacturer, or otherwise, does not necessarily constitute or imply its endorsement, recommendation, or favoring by the United States Government or any agency thereof or its contractors or subcontractors.

Printed in the United States of America. To obtain copies of this document, contact: Document Control Services, P.O. Box 950, Mailstop H6-08, Richland WA 99352, Phone (509) 372-2420; Fax (509) 376-4989.
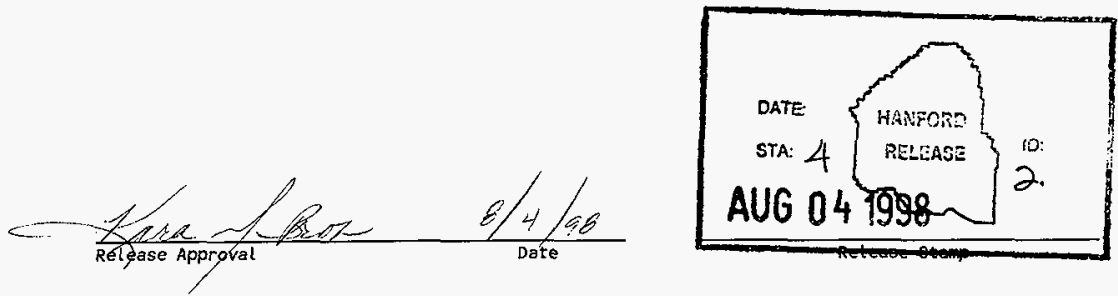

\section{Approved for Public Release}


HNF-1802

Revision 0

\section{DATA QUALITY OBJECTIVES FOR TWRS PRIVATIZATION PHASE 1: TANK WASTE TRANSFER CONTROL}

D. L. Banning

V. C. Boyles

Lockheed Martin Hanford Corporation

Date Published

July 1998

Prepared for the U.S. Department of Energy

Assistant Secretary for Environmental Management

Fluor Daniel Hanford, Inc.

P. O. Box 1000

Richland, Washington

Hanford management and Integration Contractor for the

U.S. Department of Energy under Contract DE-AC06-96-RL13200

Approved for Public Release; Further Dissemination Unlimited 
HNF-1802 Rev. 0

TABLE OF CONTENTS

1.0 INTRODUCTION . . . . . . . . . . . . . . . . . 1

2.0 STATEMENT OF THE PROBLEM . . . . . . . . . . . . . . . 2

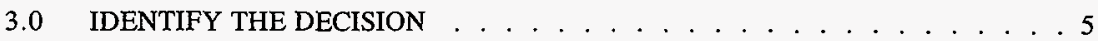

4.0 INPUTS TO THE DECISION . . . . . . . . . . . . . . . 7

5.0 DEFINE THE STUDY BOUNDARIES . . . . . . . . . . . . . . . . . . 19

6.0 DECISION RULES . . . . . . . . . . . . . . . . . . . . . . . . 19

$7.0 \quad$ SPECIFY LIMITS ON DECISION ERROR . . . . . . . . . . . . . . . . 20

8.0 OPTIMIZE THE DESIGN FOR OBTAINING DATA . . . . . . . . . . . 22

9.0 REFERENCES . . . . . . . . . . . . . . . . . 23 


\section{LIST OF FIGURES}

3-1 Decision Logic For Waste Transfers . . . . . . . . . . . . . . . 6

\section{LIST OF TABLES}

2-1 Phase 1 Privatization Campaigns Low Activity Waste . . . . . . . . . . . 3

2-2 Phase 1 Privatization Campaigns High Level Waste . . . . . . . . . . . . . 4

4-1 Information and Data Inputs Waste Transfer Into a Phase 1 Tank . . . . . . . . . 7

4-2 Information and Data Inputs Waste Transfer Out of a Phase 1 Tank . . . . . . 8

4-3 Low-Activity Waste Feed Liquid Phase Chemical Composition Limits . . . . . . . . 9

4-4 Low-Activity Waste Feed Liquid Phase Radionuclide Composition Limits . . . . . 10

4-5 High-Level Waste Feed Non-Volatile Composition Limits . . . . . . . . . . . . 11

4-6 High-Level Waste Feed Volatile Composition Limits . . . . . . . . . . . . . 11

4-7 High-Level Waste Feed Radionuclide Composition Limits . . . . . . . . . . . . 12

4-8 Operating Specifications from OSD-T-151-00007, Rev. H-16 . . . . . . . . 12

4-9 Quality Control Parameters . . . . . . . . . . . . . . . . 13

4-10 Minimum Reportable Quantities for LAW . . . . . . . . . . . . . . . 15

4-11 Minimum Reportable Quantities for HLW . . . . . . . . . . . . . . . . . . . 17 


\section{LIST OF TERMS}

\begin{tabular}{ll} 
Bq & Becquerel \\
Bq/mL & Becquerel per milliliter \\
BTU/hr & British thermal units per hour \\
Ci/L & curies per liter \\
CI & confidence interval \\
$d f$ & degrees of freedom \\
DOE-RL & U.S. Department of Energy, Richland Operations Office \\
DQO & Data Quality Objective \\
DST & Double-Shell Tank \\
FPMT & Feed Process Management Team \\
g/L & gram per liter \\
HLW & high-level waste \\
LAW & low activity waste \\
LMHC & Lockheed Martin Hanford Corporation \\
M & molar \\
mL & milliliter \\
MRQ & minimum reportable quantities \\
QC & quality control \\
RSD & relative standard deviation \\
TIC & total inorganic carbon \\
TOC & total organic carbon \\
TRU & Transuranic radionuclides \\
TWRS & Tank Waste Remediation System \\
UL & upper limit \\
WIC & Waste Inventory Control \\
$\mu$ Ci/L & microcurie per liter \\
$\mu C i / m L$ & microcurie per milliliter \\
$\mu$ g/mL & micrograms per milliliter \\
$\%$ & percent \\
\hline
\end{tabular}


HNF-1802 Rev. 0

This page intentionally left blank. 


\subsection{INTRODUCTION}

The Phase 1 privatization contracts (DOE-RL 1996) require that the Project Hanford Management Contractors, on behalf of the U.S. Department of Energy, Richland Operations Office, deliver the appropriate quantities of the proper composition of feed on schedule.

The Feed Process Management Team (FPMT) was created with responsibility for establishing requirements, identifying and recommending baseline change control, assuring configuration management of tank contents (e.g., feed pedigrees), and requiring understanding among the various TWRS elements so the right feed is produced on schedule (Boston 1996).

The FPMT has charged the Double Shell Tank (DST) Waste Inventory Control (WIC) (LMHC 1997) group to develop and implement the waste configuration control needed to insure that our ability to deliver feed on schedule is not adversely impacted. The WIC group, which has representatives from engineering, environmental, operations, and waste feed delivery, reviews proposed waste transfers and technical issues affecting the TWRS waste inventory. The WIC group either approves proposed transfers or, if a unanimous decision is not obtained, elevates approval to the FPMT. A representative from the FPMT is present at the WIC group meetings where waste transfer approvals are decided, and WIC relays information to the FPMT as needed. The TWRS waste process includes waste inventory control, waste consolidation, waste transfers, compatibility, feed staging for privatization, and technical issues affecting waste transfers. Pumping restrictions are outlined in Wicks 1997.

The mobilization, retrieval, transfer, pretreatment, staging, and delivery of feed to the privatization contractors takes place in the DST system. These tanks support multiple programs; therefore, the tank space must be allocated and controlled so as not to interfere with the delivery of feed by creating space bottle-necks or by significantly changing the composition or quantity of feed. Each feed tank selected for Phase 1 processing has been identified as a source of waste for a particular feed envelope. These feed envelope descriptions are identified in the Phase 1 privatization contracts. 


\subsection{STATEMENT OF THE PROBLEM}

Specific tanks have been selected to provide waste feed (first 12 batches identified for low level waste and first 12 batches for high level waste) to the private contractor for treatment. Any waste transfer into or out of these specific tanks has the possibility of changing the waste so it would no longer meet the required specifications for transfer to the private contractor. Therefore, any waste transfer into or out of these tanks must be controlled so the transfer does not compromise the feed envelope selected for that particular tank.

The major problem is to determine if a proposed transfer to or from a Phase 1 tank has an adverse impact on the ability to deliver feed of the proper quantities and composition on schedule from that tank during Phase 1 Privatization.

For the most part, the Phase 1 feed source tanks are nearly full, and there are no plans currently scheduled for moving the waste into or out of these tanks. Many of these tanks also have pumping restrictions (Wicks 1997) established by Lockheed Martin Hanford Corporation (LMHC) which limit waste transfers into or out of the tanks. The present restrictions for the addition or removal of waste and existing sample analyses for the waste in the Phase 1 tanks are shown in Table 2-1 for low level waste and Table 2-2 for high level waste. However, if a situation occurs where a transfer into or out of these tanks is being considered, this Data Quality Objective (DQO) would apply. This DQO does not apply to tanks before the "static date" (see Tables 2-1 and 2-2) or when waste is being retrieved for transfer to the staging tanks. The "static date" indicates when the tank is expected to contain the desired waste feed material. 
Table 2-1. Phase 1 Privatization Campaigns Low Activity Waste

\begin{tabular}{|c|c|c|c|c|c|c|}
\hline 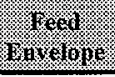 & Basis & 9ronto & (Fin: & Hown & (18) & 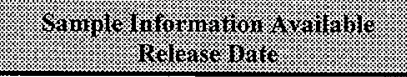 \\
\hline \multirow{6}{*}{ A } & 1 & AN-105 & 4.13 & $\begin{array}{l}\text { No waste added/removed } \\
\text { Watch list tank }\end{array}$ & Now & $\begin{array}{l}\text { WHC-SD-WM-ER-410, July } 1995 . \\
\text { PNNL-11450 Rev. 1, March } 1997 . \\
\text { HNF-SD-DTR-046, October } 1997 .\end{array}$ \\
\hline & 2 & AN-104 & 3.77 & $\begin{array}{l}\text { No waste added/removed } \\
\text { Watch list tank }\end{array}$ & Now & $\begin{array}{l}\text { HNF-SD-WM-ER-690, August } 1997 . \\
\text { PNNL-11450 Rev. 1, March } 1997 . \\
\text { PNNL-11296 }\end{array}$ \\
\hline & 3 & AW-101 & 4.27 & $\begin{array}{l}\text { No waste added/removed } \\
\text { Watch list tank }\end{array}$ & Now & $\begin{array}{l}\text { HNF-SD-WM-ER-470, August } 1997 . \\
\text { PNNL-11450 Rev. 1, March } 1997 . \\
\text { PNNL-11296 }\end{array}$ \\
\hline & 4 & $A N-103$ & 3.69 & $\begin{array}{l}\text { No waste added/removed } \\
\text { Watch list tank }\end{array}$ & Now & HNF-SD-WM-ER-709, August 1997 \\
\hline & \multirow{2}{*}{5} & AP-101 & 4.18 & \multirow{2}{*}{ No present restrictions } & $4 / 1999$ & WHC-SD-WM-ER-357, August 1994 \\
\hline & & AW-104 & 3.87 & & $10 / 1999$ & WHC-SD-WM-ER-453, July 1995 \\
\hline \multirow[b]{2}{*}{ B } & \multirow[b]{2}{*}{6} & $\mathrm{AZ}-101$ & 3.12 & \multirow[b]{2}{*}{ No waste added/removed } & Now & WHC-SD-WM-ER-410, July 1995 \\
\hline & & AZ-102 & 1.71 & & Now & WHC-SD-WM-ER-411, July 1995 \\
\hline \multirow{4}{*}{$\mathrm{C}$} & 7 & \multirow[b]{2}{*}{ AN-107 } & \multirow[b]{2}{*}{4.26} & \multirow{2}{*}{$\begin{array}{l}\text { No waste added/removed } \\
\text { Caustic addition permitted }\end{array}$} & \multirow[b]{2}{*}{ Now } & \multirow[t]{2}{*}{ WHC-SD-WM-ER-600, July 1996} \\
\hline & 8 & & & & & \\
\hline & 9 & AN-102 & 4.07 & $\begin{array}{l}\text { No waste added/removed } \\
\text { Caustic addition permitted }\end{array}$ & Now & WHC-SD-WM-ER-545, March 1996 \\
\hline & 10 & AN-106 & 4.32 & No present restrictions & $7 / 1999$ & WHC-SD-WM-ER-569, July 1996 \\
\hline \multirow[t]{2}{*}{$\mathrm{C}$} & 11 & SY-101 & 4.28 & $\begin{array}{l}\text { No waste added/removed } \\
\text { Watch list tank }\end{array}$ & Now & $\begin{array}{l}\text { WHC-SD-WM-ER-409, August } 1.995 . \\
\text { PNNL-11296 }\end{array}$ \\
\hline & 12 & SY -103 & 2.79 & $\begin{array}{l}\text { No waste added/removed } \\
\text { Watch list tank }\end{array}$ & Now & $\begin{array}{l}\text { WHC-SD-WM-ER-471, September } \\
\text { 1996. PNNL-11296, September } 1996\end{array}$ \\
\hline
\end{tabular}


Table 2-2. Phase 1 Privatization Campaigns High Level Waste

\begin{tabular}{|c|c|c|c|c|c|c|}
\hline 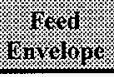 & (6on & S1010\% & 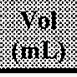 & 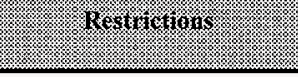 & 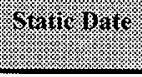 & 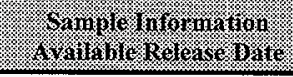 \\
\hline \multirow{12}{*}{$\mathrm{D}$} & 1 & \multirow[t]{2}{*}{ AZ-101 } & \multirow[t]{2}{*}{0.18} & \multirow[t]{2}{*}{ No waste added/removed } & \multirow[t]{2}{*}{ Now } & \multirow{2}{*}{$\begin{array}{l}\text { WHC-SD-WM-ER-410 } \\
\text { August } 1997\end{array}$} \\
\hline & 2 & & & & & \\
\hline & 3 & \multirow[t]{2}{*}{ AZ-102 } & \multirow[t]{2}{*}{0.39} & \multirow[t]{2}{*}{ No waste added/removed } & \multirow[t]{2}{*}{ Now } & \multirow{2}{*}{$\begin{array}{l}\text { WHC-SD-WM-ER-411 } \\
\text { August } 1997\end{array}$} \\
\hline & 4 & & & & & \\
\hline & 5 & \multirow{3}{*}{ AY -102} & \multirow{3}{*}{0.08} & \multirow{4}{*}{$\begin{array}{l}\text { No sludge removed } \\
\text { Only C-106 sludge may } \\
\text { be added } \\
\text { No present restrictions } \\
\text { on supernate }\end{array}$} & & \multirow{4}{*}{$\begin{array}{l}\text { WHC-SD-WM-ER-454 } \\
\text { August } 1997\end{array}$} \\
\hline & 6 & & & & & \\
\hline & 7 & & & & & \\
\hline & 8 & \multirow{2}{*}{ C-106 } & \multirow{2}{*}{0.75} & & \multirow{2}{*}{ Now } & \\
\hline & 9 & & & $\begin{array}{l}\text { Single-shell tank } \\
\text { No waste added }\end{array}$ & & $\begin{array}{l}\text { WHC-SD-WM-ER-615 } \\
\text { August } 1997\end{array}$ \\
\hline & 10 & \multirow{3}{*}{ C-104 } & \multirow{3}{*}{1.12} & \multirow{3}{*}{$\begin{array}{l}\text { Single-shell tank } \\
\text { No waste added }\end{array}$} & \multirow{3}{*}{ Now } & \multirow{3}{*}{$\begin{array}{l}\text { HNF-SD-WM-ER-679 } \\
\text { August } 1997\end{array}$} \\
\hline & 11 & & & & & \\
\hline & 12 & & & & & \\
\hline
\end{tabular}




\subsection{IDENTIFY THE DECISION}

Decisions must be made on three questions to address the problem outlined in Section 2.0. The three decision questions are:

1. Will a proposed waste addition into a Phase 1 static tank still result in that Phase 1 tank meeting the waste feed specification for that tank?

2. If the proposed waste transfer into a Phase 1 tank does not meet the feed specifications for that Phase 1 tank, does the waste transfer impact the ability to deliver feed of the proper quantities and composition on schedule during Phase 1 Privatization?

3. Does a proposed waste transfer out of a Phase 1 tank impact the ability to deliver feed of the proper quantities and composition on schedule during Phase 1 Privatization?

The decision logic for accepting or rejecting a proposed waste transfer into or out of the tanks covered by this DQO (see Tables 2-1 and 2-2) is shown in Figure 3-1.

Depending on the quantity, waste may be transferred into a Phase 1 tank even if it does not meet waste feed specifications. This may be permitted if the quantity of waste is sufficiently small that the composition of the resulting feed batch remains within specifications. The decision to transfer waste into a Phase 1 tank, when the incoming waste does not meet waste feed specifications, is made by the WIC group. The WIC group also makes the ultimate decision on all transfers scheduled to be made out of a Phase 1 tank. In addition, the WIC group makes the decision to transfer waste for Envelopes $\mathrm{B}$ and $\mathrm{C}$ waste in all instances where the discriminating analytes (see the first decision rule, Section 6.0 ) are not the same. 
Figure 3-1. Decision Logic For Waste Transfers

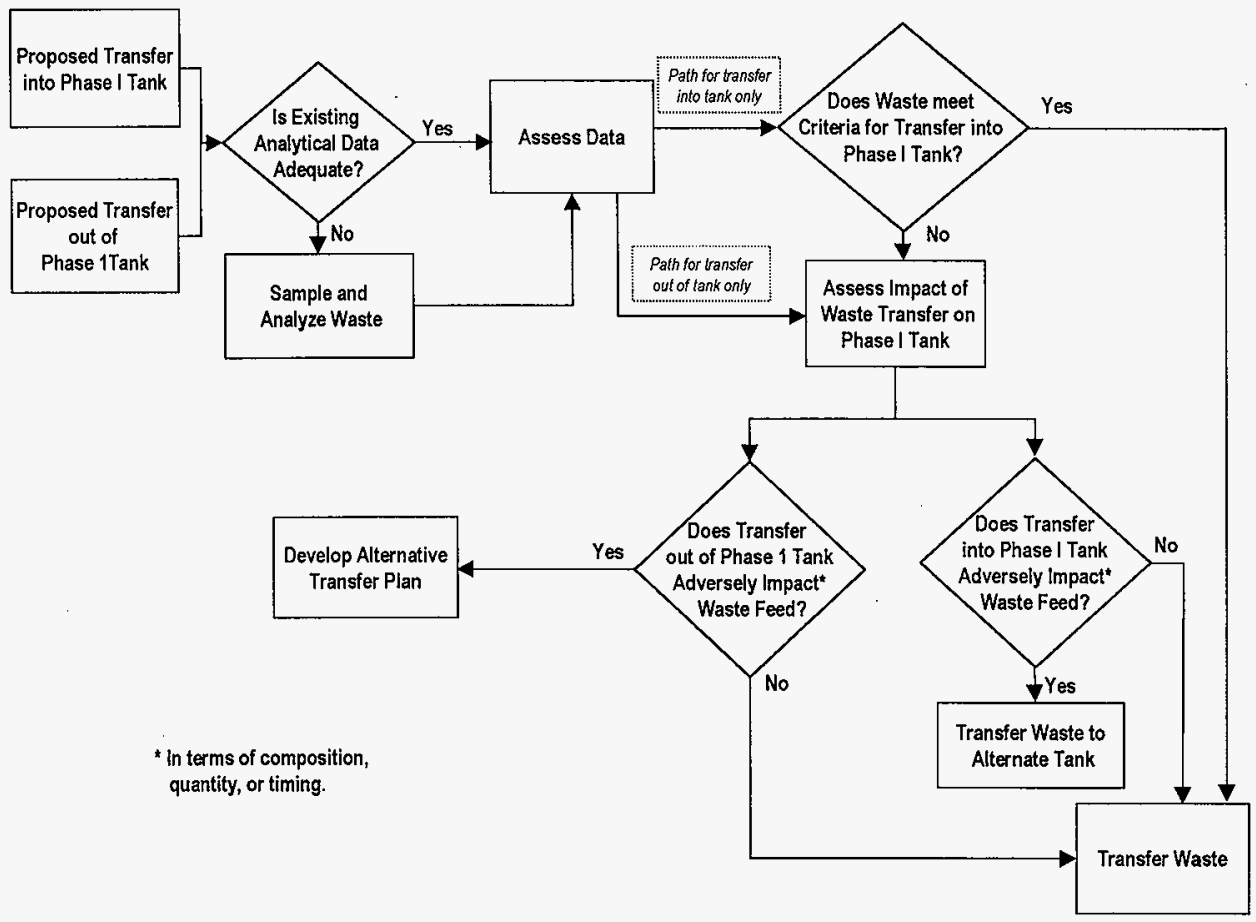




\subsection{INPUTS TO THE DECISION}

The existing waste transfer compatibility program (Fowler 1995) formalizes the process for determining waste compatibility in terms of both safety and waste management considerations. A transfer assessment is performed on each proposed waste transfer prior to performing the transfer. The detailed rules used in the transfer assessment are documented in Data Quality Objectives for Tank Farms Waste Compatibility Program (Mulkey and Miller 1997). The Compatibility DQO was prepared to address safe storage and management of waste. Waste acceptance into the DST system is controlled by the approval of incoming waste streams as documented in waste stream profile sheets, existing DST system plant operating procedures, and the Compatibility DQO. Any transfers to the tanks covered in this DQO (Phase 1 tanks shown in Tables 2-1 and 2-2) would be required to meet the sampling and analysis requirements discussed in this $\mathrm{DQO}$, as well as existing waste transfer requirements.

Table 4-1 shows the data input required to make a decision on the transfer of waste into a Phase 1 tank. These data will allow a decision to be made on questions 1 and 2 in Section 3.0.

Table 4-1. Information and Data Inputs Waste Transfer Into a Phase 1 Tank

\begin{tabular}{|c|c|c|}
\hline Imprit & Rerson for linclusion & 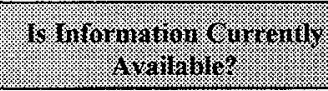 \\
\hline $\begin{array}{l}\mathrm{Na} \\
\text { (for tank waste and } \\
\text { incoming waste) }\end{array}$ & $\begin{array}{l}\text { Required to determine envelope } \\
\text { specifications for waste feed } \\
\text { and the quantity of feed. }\end{array}$ & $\begin{array}{l}\text { Available for Phase } 1 \text { tank } \\
\text { contents. } \\
\text { Needed for incoming waste. }\end{array}$ \\
\hline $\begin{array}{l}\text { Envelope analytes } \\
\text { (see Tables } 4-3,4-4,4-5 \text {, } \\
4-6 \text {, and 4-7) }\end{array}$ & $\begin{array}{l}\text { Required to determine envelope } \\
\text { specifications for waste feed } \\
\text { and which envelope the waste } \\
\text { matches. }\end{array}$ & $\begin{array}{l}\text { Available for Phase } 1 \text { tank } \\
\text { contents. } \\
\text { Needed for incoming waste. }\end{array}$ \\
\hline Solids content & $\begin{array}{l}\text { Required to meet waste feed } \\
\text { specifications. }\end{array}$ & $\begin{array}{l}\text { Needed for incoming waste } \\
\text { only. }\end{array}$ \\
\hline $\begin{array}{l}\text { OSD-T-151-00007, Rev. } \\
\text { H-16 specifications } \\
\text { (PHMC 1997) (see } \\
\text { Table 4.8) }\end{array}$ & $\begin{array}{l}\text { Required to meet waste feed } \\
\text { heat generation and corrosion } \\
\text { specification. }\end{array}$ & $\begin{array}{l}\text { Needed for incoming waste } \\
\text { only. }\end{array}$ \\
\hline $\begin{array}{l}\text { Volume of waste } \\
\text { (in the tank and to be } \\
\text { transferred) }\end{array}$ & $\begin{array}{l}\text { Required to determine impact } \\
\text { on waste in the tank if the } \\
\text { incoming waste does not meet } \\
\text { feed specifications. }\end{array}$ & $\begin{array}{l}\text { Available for Phase } 1 \text { tank } \\
\text { contents. } \\
\text { Needed for incoming waste. }\end{array}$ \\
\hline
\end{tabular}


Table 4-2 shows the data input required to make a decision on the transfer of waste out of a Phase 1 tank. These data will allow a decision to be made on question 3 in Section 3.0.

Table 4-2. Information and Data Inputs Waste Transfer Out of a Phase 1 Tank

\begin{tabular}{|c|c|c|}
\hline lippuit & 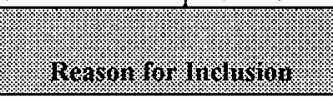 & 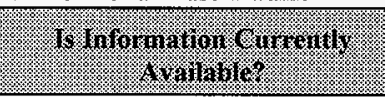 \\
\hline $\mathrm{Na}$ (for tank waste) & $\begin{array}{l}\text { Required to determine } \\
\text { envelope specifications for } \\
\text { waste feed. }\end{array}$ & $\begin{array}{l}\text { Available for Phase } 1 \text { tank } \\
\text { contents. }\end{array}$ \\
\hline $\begin{array}{l}\text { Envelope analytes (see } \\
\text { Tables 4-3, 4-4, 4-5, } \\
4-6 \text {, and 4-7) }\end{array}$ & $\begin{array}{l}\text { Required to determine } \\
\text { envelope specifications for } \\
\text { waste feed and which } \\
\text { envelope the waste matches. }\end{array}$ & $\begin{array}{l}\text { Available for Phase } 1 \text { tank } \\
\text { contents. }\end{array}$ \\
\hline $\begin{array}{l}\text { Dissolution/Dilution } \\
\text { testing (dissolving solids } \\
\text { and analyzing the results } \\
\text { for Na and envelope } \\
\text { limit analytes) }\end{array}$ & $\begin{array}{l}\text { Required to determine if } \\
\text { remaining waste (solids) } \\
\text { would meet envelope limits } \\
\text { after removal of supernate. }\end{array}$ & $\begin{array}{l}\text { Available for tank } 241-\mathrm{AN}-105 \\
\text { only. Determination for other } \\
\text { tanks is underway (not required } \\
\text { for tanks AN-102, AN-106, AN- } \\
107, \mathrm{AP}-101, \mathrm{AW}-104, \mathrm{AZ}-101 \text {, } \\
\text { and AZ-102). }\end{array}$ \\
\hline $\begin{array}{l}\text { Quantity of waste to be } \\
\text { transferred }\end{array}$ & $\begin{array}{l}\text { Required to determine if } \\
\text { enough waste remains to } \\
\text { meet feed quantity } \\
\text { requirements. }\end{array}$ & No transfers planned at this time. \\
\hline
\end{tabular}

For waste transferred into a Phase 1 tank, the main data requirement is to meet the waste feed envelopes. There are four (A, B, C, and D) feed envelopes (DOE-RL 1996), which have been applied to the feed batches and tanks (see Tables 2-1 and 2-2). Feed envelope requirements for Envelopes A, B, and C (low activity waste [LAW]) and the applicable tanks are shown in Table 4-3 for the chemical constituents and Table 4-4 for the radionuclide constituents. Feed envelope requirements for Envelope D (high level waste [HLW]) and the applicable tanks are shown in Tables 4-5 (non-volatile elements), 4-6 (volatile elements), and 4-7 (radionuclides).

In addition to the waste feed envelope requirements, the low activity waste (Table 2-1) feed must meet the operating specifications found in OSD-T-151-00007, Rev. H-16 (PHMC 1997) (Table 4-8), sodium concentration requirements, and solids content. The sodium requirement for the waste feed is: $3 \mathrm{M} \leq[\mathrm{Na}] \leq 14 \mathrm{M}$. The insoluble solids fraction will not exceed 5 volume percent of the waste transferred as waste envelopes A, B, and C. The solids requirement is expected to change to $2 \%$ (dry weight) in the next revision of the waste feed specifications. 
Table 4-3. Low-Activity Waste Feed Chemical Composition Limits (Envelopes A, B, and C).

\begin{tabular}{|c|c|c|c|}
\hline \multirow{2}{*}{ Gromingro } & \multicolumn{3}{|c|}{ 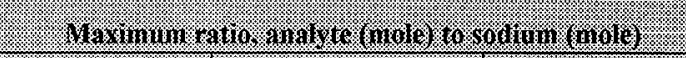 } \\
\hline & Enveropox & 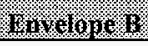 & 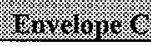 \\
\hline $\mathrm{Al}$ & $1.9 \mathrm{E}-01$ & $1.9 \mathrm{E}-01$ & $1.9 \mathrm{E}-01$ \\
\hline $\mathrm{Ba}$ & $1.0 \mathrm{E}-04$ & $1.0 \mathrm{E}-04$ & $1.0 \mathrm{E}-04$ \\
\hline $\mathrm{Ca}$ & 4.0E-02 & 4. $0 \mathrm{E}-02$ & 4.0E-02 \\
\hline $\mathrm{Cd}$ & $4.0 \mathrm{E}-03$ & $4.0 \mathrm{E}-03$ & 4.0E-03 \\
\hline $\mathrm{Cl}$ & 3.7E- 02 & $8.9 \mathrm{E}-02$ & $3.7 \mathrm{E}-02$ \\
\hline $\mathrm{Cr}$ & $6.9 \mathrm{E}-03$ & $2.0 \mathrm{E}-02$ & $6.9 \mathrm{E}-03$ \\
\hline $\mathrm{F}$ & $9.1 \mathrm{E}-02$ & $2.0 \mathrm{E}-01$ & $9.1 \mathrm{E}-02$ \\
\hline $\mathrm{Fe}$ & $1.0 \mathrm{E}-02$ & 1.0E-02 & $1.0 \mathrm{E}-02$ \\
\hline $\mathrm{Hg}$ & $1.4 \mathrm{E}-05$ & $1.4 \mathrm{E}-05$ & $1.4 \mathrm{E}-05$ \\
\hline $\mathrm{K}$ & $1.8 \mathrm{E}-01$ & $1.8 \mathrm{E}-01$ & $1.8 \mathrm{E}-01$ \\
\hline $\mathrm{La}$ & $8.3 \mathrm{E}-05$ & $8.3 \mathrm{E}-05$ & $8.3 \mathrm{E}-05$ \\
\hline $\mathrm{Ni}$ & $3.0 \mathrm{E}-03$ & $3.0 \mathrm{E}-03$ & $3.0 \mathrm{E}-03$ \\
\hline $\mathrm{NO}_{2}$ & $3.8 \mathrm{E}-01$ & $3.8 \mathrm{E}-01$ & $3.8 \mathrm{E}-01$ \\
\hline $\mathrm{NO}_{3}$ & $8.0 \mathrm{E}-01$ & $8.0 \mathrm{E}-01$ & $8.0 \mathrm{E}-01$ \\
\hline $\mathrm{OH}$ & 7.0E-01 & $7.0 \mathrm{E}-01$ & 7.0E-01 \\
\hline $\mathrm{Pb}$ & $6.8 \mathrm{E}-04$ & $6.8 \mathrm{E}-04$ & $6.8 \mathrm{E}-04$ \\
\hline $\mathrm{PO}_{4}$ & $3.8 \mathrm{E}-02$ & 1.3E-01 & $3.8 \mathrm{E}-02$ \\
\hline $\mathrm{SO}_{4}$ & $9.7 \mathrm{E}-03$ & $7.0 \mathrm{E}-02$ & $2.0 \mathrm{E}-02$ \\
\hline TIC & $3.0 \mathrm{E}-01$ & $3.0 \mathrm{E}-01$ & $3.0 \mathrm{E}-01$ \\
\hline TOC $^{1}$ & $6.0 \mathrm{E}-02$ & $6.0 \mathrm{E}-02$ & $5.0 \mathrm{E}-01$ \\
\hline$U$ & $1.2 \mathrm{E}-03$ & $1.2 \mathrm{E}-03$ & $1.2 \mathrm{E}-03$ \\
\hline
\end{tabular}

${ }^{\mathrm{l}}$ For each atom of carbon in TOC.

TIC $=$ Total inorganic carbon

$\mathrm{TOC}=$ Total organic carbon 
Table 4-4. Low-Activity Waste Feed Radionuclide Composition Limits (Envelopes A, B, and C).

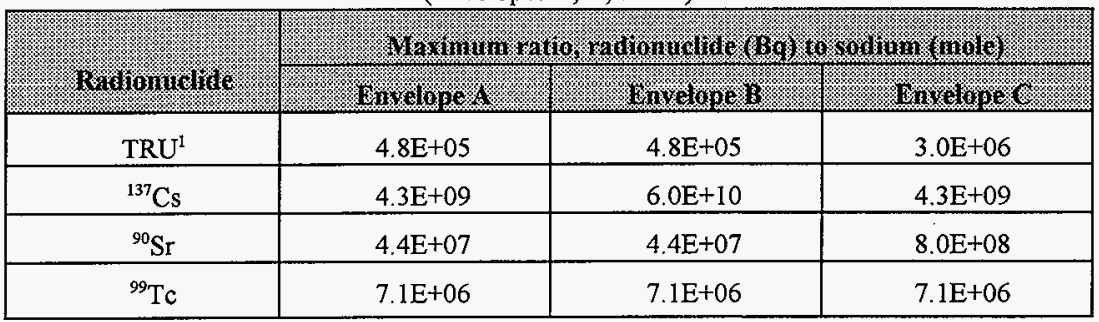

'TRU is defined as those alpha-emitting transuranic radionuclides with half-lives greater than 5 years $\left({ }^{236} \mathrm{~Np}\right.$, ${ }^{237} \mathrm{~Np},{ }^{238} \mathrm{Pu},{ }^{239} \mathrm{Pu},{ }^{240} \mathrm{Pu},{ }^{242} \mathrm{Pu},{ }^{244} \mathrm{Pu},{ }^{241} \mathrm{Am},{ }^{242 \mathrm{~m}} \mathrm{Am},{ }^{243} \mathrm{Am},{ }^{243} \mathrm{Cm},{ }^{244} \mathrm{Cm},{ }^{245} \mathrm{Cm},{ }^{246} \mathrm{Cm}$, and ${ }^{247} \mathrm{Cm}$ ).

Total Alpha will be used as a conservative (biased high) indication of the TRU content. The individual radionuclides that contribute to the TRU content will be measured only when the Total Alpha exceeds the TRU envelope limits.

Waste Feed Delivery will not plan to deliver Envelope A feed as Envelope B or C. Therefore, at least one of the Envelope $\mathrm{A}$ maximum limits for $\mathrm{Cl}, \mathrm{Cr}, \mathrm{F}, \mathrm{PO}_{4}$, or $\mathrm{SO}_{4}$ must be exceeded for waste to be delivered as Envelope $\mathrm{B}$ feed. In addition, at least one of the Envelope A maximum limits for ${ }^{90} \mathrm{Sr}$ or TRU must be exceeded for delivery as Envelope $\mathrm{C}$ feed. For the purposes of this DQO, these analytes are referred to as the "discriminating" analytes. 
HNF-1802 Rev. 0

Table 4-5. High-Level Waste Feed Non-Volatile Composition Limits

(Envelope D)

\begin{tabular}{|c|c|c|c|c|c|c|c|}
\hline $\begin{array}{l}\text { Non } \\
\text { yourno } \\
\text { 8lement }\end{array}$ & Waminuin & 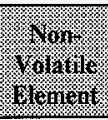 & 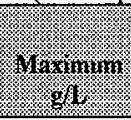 & 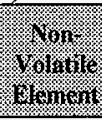 & yinininit & 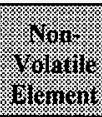 & 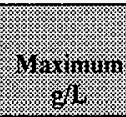 \\
\hline $\mathrm{Ag}$ & 0.55 & $\mathrm{Cu}$ & 0.48 & $\mathbf{P}$ & 1.7 & $\mathrm{Sr}$ & 0.52 \\
\hline $\mathrm{Al}$ & 14 & $\mathrm{~F}$ & 3.5 & $\mathrm{~Pb}$ & 1.1 & $\mathrm{Ta}$ & 0.03 \\
\hline As & 0.16 & $\mathrm{Fe}$ & 29 & $\mathrm{Pd}$ & 0.13 & $\mathrm{Tc}$ & 0.26 \\
\hline B & 1.3 & $\mathrm{Hg}$ & 0.1 & $\mathrm{Pm}$ & 0.03 & $\mathrm{Te}$ & 0.13 \\
\hline $\mathrm{Ba}$ & 4.5 & $\mathrm{~K}$ & 1.3 & $\operatorname{Pr}$ & 0.35 & Th & 0.52 \\
\hline $\mathrm{Be}$ & 0.065 & $\mathrm{La}$ & 2.6 & $\mathrm{Pu}$ & 0.054 & $\mathrm{Ti}$ & 1.3 \\
\hline $\mathrm{Bi}$ & 2.8 & $\mathrm{Li}$ & 0.14 & $\mathrm{Rb}$ & 0.19 & $\mathrm{Tl}$ & 0.45 \\
\hline $\mathrm{Ca}$ & 7.1 & $\mathrm{Mg}$ & 2.1 & $\mathrm{Rh}$ & 0.13 & $\mathrm{U}$ & 14 \\
\hline $\mathrm{Cd}$ & 4.5 & $\mathrm{Mn}$ & 6.5 & $\mathrm{Ru}$ & 0.35 & $\mathrm{~V}$ & 0.032 \\
\hline $\mathrm{Ce}$ & 0.81 & Mo & 0.65 & $S$ & 0.65 & W & 0.24 \\
\hline Co & 0.45 & $\mathrm{Na}$ & 19 & $\mathrm{Sb}$ & 0.84 & $Y$ & 0.16 \\
\hline $\mathrm{Cr}$ & 0.68 & $\mathrm{Nd}$ & 1.7 & $\mathrm{Se}$ & 0.52 & $\mathrm{Zn}$ & 0.42 \\
\hline $\mathrm{Cs}$ & 0.58 & $\mathrm{Ni}$ & 2.4 & $\mathrm{Si}$ & 19 & $\mathrm{Zr}$ & 15 \\
\hline
\end{tabular}

Table 4-6. High-Level Waste Feed Volatile Composition Limits

(Envelope D)

\begin{tabular}{|c|c|}
\hline Yotanit comportents & Navinuming \\
\hline $\mathrm{Cl}^{-}$ & 0.33 \\
\hline $\mathrm{TIC} / \mathrm{CO}_{3}{ }^{2-}$ & 30 \\
\hline $\mathrm{NO}_{2}{ }^{-}$ & \multirow{2}{*}{$\begin{array}{c}36 \\
\text { (total } \mathrm{NO}_{2}^{-} / \mathrm{NO}_{3}{ }^{-} \text {) } \\
\text { as } \mathrm{NO}_{3}^{-}\end{array}$} \\
\hline $\mathrm{NO}_{3}^{-}$ & \\
\hline TOC & 11 \\
\hline $\mathrm{CN}^{-}$ & 1.6 \\
\hline $\mathrm{NH}_{3} / \mathrm{NH}_{4}{ }^{+}$ & 1.6 \\
\hline
\end{tabular}


HNF-1802 Rev. 0

Table 4-7. High-Level Waste Feed Radionuclide Composition Limits (Envelope D)

\begin{tabular}{|c|c|c|c|c|c|}
\hline Isntope & $\begin{array}{l}\text { Muranon } \\
\text { cint }\end{array}$ & Iroviope & Marinum & Arotoge & 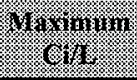 \\
\hline${ }^{3} \mathrm{H}$ & $6.5 \mathrm{E}-05$ & ${ }^{129} \mathrm{I}$ & $2.9 \mathrm{E}-07$ & ${ }^{238} \mathrm{Pu}$ & $3.5 \mathrm{E}-04$ \\
\hline${ }^{14} \mathrm{C}$ & $6.5 \mathrm{E}-06$ & ${ }^{137} \mathrm{Cs}$ & $1 E+01$ & ${ }^{239} \mathrm{Pu}$ & $3.1 \mathrm{E}-03$ \\
\hline${ }^{60} \mathrm{Co}$ & $1 \mathrm{E}-02$ & ${ }^{152} \mathrm{Eu}$ & $4.8 \mathrm{E}-04$ & ${ }^{241} \mathrm{Pu}$ & 2.2E- 02 \\
\hline${ }^{90} \mathrm{Sr}$ & $1 E+01$ & ${ }^{154} \mathrm{Eu}$ & $5.2 \mathrm{E}-02$ & ${ }^{241} \mathrm{Am}$ & $9 \mathrm{E}-02$ \\
\hline${ }^{99} \mathrm{Tc}$ & $1.5 \mathrm{E}-02$ & ${ }^{155} \mathrm{Eu}$ & $2.9 \mathrm{E}-02$ & ${ }^{243+244} \mathrm{Cm}$ & $3 \mathrm{E}-03$ \\
\hline${ }^{125} \mathrm{Sb}$ & $3.2 \mathrm{E}-02$ & ${ }^{233} \mathrm{U}$ & $9 \mathrm{E}-07$ & & \\
\hline${ }^{126} \mathrm{Sn}$ & $1.5 \mathrm{E}-04$ & ${ }^{235} \mathrm{U}$ & $2.5 \mathrm{E}-07$ & & \\
\hline
\end{tabular}

Table 4-8. Operating Specifications from OSD-T-151-00007, Rev. H-16 (PHMC 1997)

\begin{tabular}{|c|c|}
\hline 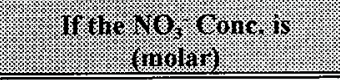 & 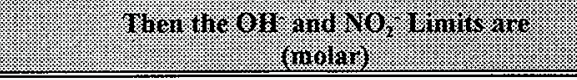 \\
\hline$\leq 1.0 \mathrm{M}$ & $\begin{array}{c}0.01<\left[\mathrm{OH}^{-}\right]<5.0 \mathrm{M}\left(8.0 \mathrm{M} \text { if } \mathrm{T}<167^{\circ} \mathrm{F}\right) \\
0.011<\left[\mathrm{NO}_{2}^{-}\right]<5.5 \mathrm{M} \\
{\left[\mathrm{NO}_{3}^{-}\right] /\left(\left[\mathrm{OH}^{-}\right]+\left[\mathrm{NO}_{2}^{-}\right]\right)<2.5}\end{array}$ \\
\hline 1.0 to $3.0 \mathrm{M}$ & $\begin{array}{c}0.1^{*}\left[\mathrm{NO}_{3}^{-}\right]<\left[\mathrm{OH}^{-}\right]<10 \mathrm{M} \\
{\left[\mathrm{NO}_{2}^{-}\right]+\left[\mathrm{OH}^{-}\right] \geq 0.4^{*}\left[\mathrm{NO}_{3}^{-}\right]}\end{array}$ \\
\hline 3.0 to $5.5 \mathrm{M}$ & $\begin{array}{c}0.3<\left[\mathrm{OH}^{-}\right]<10 \mathrm{M} \\
{\left[\mathrm{NO}_{2}^{-}\right]+\left[\mathrm{OH}_{-}\right] \geq 1.2 \mathrm{M}}\end{array}$ \\
\hline & 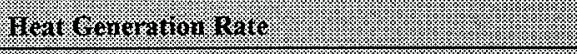 \\
\hline Variable & Spectichitron lingt: \\
\hline Max. Heat Generation Rate & $70,000 \mathrm{BTU} / \mathrm{hr}$ \\
\hline Max. Cs-137 Concentration & $5.74 \times 10^{5} \mu \mathrm{Ci} / \mathrm{L}$ \\
\hline Max. Sr-90 Concentration & $4.04 \times 10^{5} \mu \mathrm{Ci} / \mathrm{L}$ \\
\hline
\end{tabular}

Table 4-9 shows the analytes that require analyses, suggested analytical methods, and the quality control requirements. The elements marked with (TRU) and total alpha are required to determine the total transuranic radionuclides so a comparison can be made with the envelope limit for TRU (see Table 4-4). 
Table 4-9. Quality Control Parameters. (3 sheets)

\begin{tabular}{|c|c|c|c|c|}
\hline \multirow{2}{*}{ 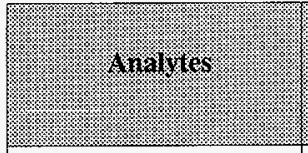 } & \multirow[b]{2}{*}{ 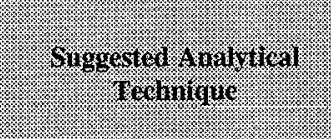 } & \multicolumn{3}{|c|}{ 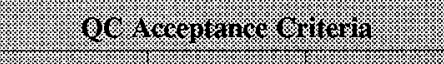 } \\
\hline & & 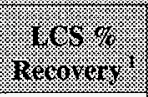 & inconich & Iyplicatis \\
\hline $\begin{array}{l}\mathrm{Ag}, \mathrm{Al}, \mathrm{As}, \mathrm{B}, \mathrm{Ba}, \mathrm{Be} \\
\mathrm{Bi}, \mathrm{Ca}, \mathrm{Cd}, \mathrm{Ce}, \mathrm{Co}, \\
\mathrm{Cs}, \mathrm{Cu}, \mathrm{Cr}, \mathrm{Fe}, \mathrm{La}, \\
\mathrm{Mg}, \mathrm{Mn}, \mathrm{Mo}, \mathrm{Na}, \mathrm{Nd}, \\
\mathrm{Ni}, \mathrm{P}, \mathrm{Pb}, \mathrm{Pd}, \mathrm{Pu}, \mathrm{S} \\
\mathrm{Sb}, \mathrm{Se}, \mathrm{Si}, \mathrm{Sr}, \mathrm{Tc}, \mathrm{Ta} \\
\text { Th, Ti, Tl, U, V, W, } \\
\mathrm{Zn}, \mathrm{Zr}\end{array}$ & ICP/AES & $80-120 \%$ & $75-125 \%$ & $<20 \%$ \\
\hline $\begin{array}{l}\mathrm{K}, \mathrm{Li}, \mathrm{Pm}, \mathrm{Pr}, \mathrm{Rb} \\
\mathrm{Rh}, \mathrm{Ru}, \mathrm{Te}\end{array}$ & ICP/MS & $80-120 \%$ & $70-130 \%$ & $<20 \%$ \\
\hline${ }^{60} \mathrm{Co},{ }^{125} \mathrm{Sb}$ & GEA & $80-120 \%$ & $\mathrm{~N}^{\prime} \mathrm{A}^{5}$ & $<20 \%$ \\
\hline${ }^{129} \mathrm{I},{ }^{126} \mathrm{Sn},{ }^{233} \mathrm{U},{ }^{235} \mathrm{U}$ & ICP/MS & $80-120 \%$ & $70-130 \%$ & $<20 \%$ \\
\hline${ }^{99} \mathrm{Tc}$ & $\begin{array}{l}\text { ICP/MS and isotopic } \\
\text { specific separation/ AEA }\end{array}$ & $80-120 \%$ & $70-130 \%$ & $<20 \%$ \\
\hline $\mathrm{Hg}$ & CVAA & $80-120 \%$ & $75-125 \%$ & $<20 \%$ \\
\hline $\mathrm{NO}_{2}^{-}, \mathrm{NO}_{3}^{-}, \mathrm{F}^{-}, \mathrm{Cl}^{-}$ & ISE or IC & $80-120 \%$ & $75-125 \%$ & $<20 \%$ \\
\hline $\mathrm{OH}^{-}$ & Potentiometric titration & $80-120 \%$ & N/A & $<20 \%$ \\
\hline${ }^{90} \mathrm{Sr}$ & $\begin{array}{l}\text { isotopic specific } \\
\text { separation/beta count }\end{array}$ & $75-125 \%$ & $N / A^{4}$ & $<20 \%$ \\
\hline${ }^{14} \mathrm{C}$ & separation/liq. Scintillation & $80-120 \%$ & $75-125 \%$ & $<20 \%$ \\
\hline${ }^{3} \mathrm{H}$ & separation/liq. Scintillation & $80-120 \%$ & $\mathrm{~N} / \mathrm{A}^{4}$ & $<20 \%$ \\
\hline${ }^{237} \mathrm{~Np} \quad$ (TRU) & ICP/MS & $90-110 \%$ & $75-125 \%$ & $<20 \%$ \\
\hline${ }^{238 / 239 / 240 / 242} \mathrm{Pu} \quad$ (TRU) & ICP/MS & $\begin{array}{l}{ }^{80}-120 \% \\
{ }^{239} \mathrm{Pu} \text { only }\end{array}$ & $\begin{array}{l}70-130 \% \\
{ }^{239} \mathrm{Pu} \text { only }\end{array}$ & $<20 \%$ \\
\hline${ }^{241} \mathrm{Pu} / \mathrm{Am} \quad$ (TRU) & ICP/MS & $\begin{array}{c}80-120 \% \\
{ }^{241} \mathrm{Am} \text { only }\end{array}$ & $\begin{array}{l}70-130 \% \\
{ }^{241} \mathrm{Am} \text { only } \\
\end{array}$ & $<20 \%$ \\
\hline${ }^{241} \mathrm{Am} \quad$ (TRU) & separation/AEA & $80-120 \%$ & $\mathrm{~N} / \mathrm{A}^{4}$ & $<20 \%$ \\
\hline${ }^{242} \mathrm{Cm}$ (TRU) & see note ${ }^{6}$ & & & \\
\hline${ }^{243+244} \mathrm{Cm} \quad$ (TRU) & separation/AEA & NP & $\mathrm{N} / \mathrm{A}^{4}$ & $<20 \%$ \\
\hline${ }^{243} \mathrm{Am} / \mathrm{Cm} \quad$ (TRU) & ICP/MS & $90-110 \%$ & $75-125 \%$ & $<20 \%$ \\
\hline
\end{tabular}


Table 4-9. Quality Control Parameters. (3 sheets)

\begin{tabular}{|c|c|c|c|c|}
\hline \multirow[b]{2}{*}{ Horleses. } & \multirow[b]{2}{*}{ 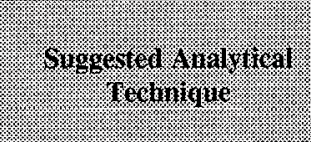 } & \multicolumn{3}{|c|}{ Q10 Aceentaned Chiteria } \\
\hline & & mecorcit: & 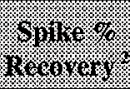 & 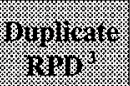 \\
\hline Total Alpha & proportional counter & $70-130 \%$ & $70-130 \%$ & $<20 \%$ \\
\hline $\mathrm{TIC} / \mathrm{CO}_{3}^{-}$ & $\begin{array}{l}\text { persulfate and combustion } \\
\text { furnace }\end{array}$ & $80-120 \%$ & $75-125 \%$ & $<20 \%$ \\
\hline TOC & $\begin{array}{l}\text { silver catalyzed persulfate } \\
\text { and combustion furnace }\end{array}$ & $80-120 \%$ & $75-125 \%$ & $<20 \%$ \\
\hline Volume \% solids & gravimetric & $80-120 \%$ & N/A & $<20 \%$ \\
\hline
\end{tabular}

Notes: AEA $=$ Alpha energy analysis
CVAA $=$ cold vapor atomic absorption
GEA $=$ gamma emission analysis
IC $=$ Ion Chromatography
ICP/AES = Inductively coupled plasma/atomic emission spectroscopy
ICP/MS $=$ ICP/mass spectrometry
ISE $=$ Ion Selective Electrode
N/A $=$ Not applicable
NP $=$ Not performed
QC $=$ Quality control
TIC $=$ total inorganic carbon
TOC $=$ total organic carbon

${ }^{1}$ LCS $=$ Laboratory Control Standard. This standard is carried through the entire method. The accuracy of a method is usually expressed as the percent recovery of the LCS. The LCS is a matrix with known concentration of analytes processed with each preparation and analyses batch. It is expressed as percent recovery; i.e., the amount measured, divided by the known concentration, times 100 .

${ }^{2}$ For some methods, the sample accuracy is expressed as the percent recovery of a matrix spike (MS) sample. It is expressed as percent recovery; i.e., the amount measured, less the amount in the sample, divided by the spike added, times 100 . One matrix spike is performed/analytical batch samples are batched with similar matrices.

${ }^{3}$ RPD = Relative Percent Difference between the sample and duplicate results. Duplicates will be taken through preparation and analysis. Instrument analysis duplicates cannot be substituted except GEA which requires no preparation. Sample precision is estimated by analyzing duplicates.

Acceptable sample precision is usually $<20$ percent RPD if the sample result is at least 10 times the instrument detection limit.

$$
R P D=(\mid \text { Result } 1-\text { Result } 2 \mid \text { /average result }) \times 100
$$

${ }^{4}$ MS analyses are not required for this method because a tracer is used to correct for analyte loss during sample preparation and analysis. The result generated using the tracer accounts for an inaccuracy of the method on the matrix. The reported results reflect this correction. 
Table 4-9. Quality Control Parameters. (3 sheets)

\begin{tabular}{|c|c|c|c|c|}
\hline \multirow{2}{*}{ Aralgtes: } & \multirow{2}{*}{ 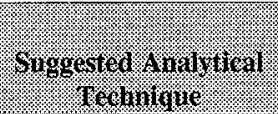 } & \multicolumn{3}{|c|}{ 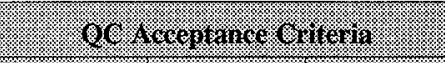 } \\
\hline & & 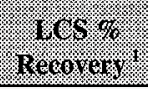 & $\begin{array}{l}\text { somer } \\
\text { necovert? }\end{array}$ & Pupilicat \\
\hline
\end{tabular}

${ }^{s}$ The measurement is a direct reading of the energy and the analysis is not affected by the sample matrix; therefore, an MS is not required.

${ }^{6}$ This isotope can not be quantitated because of the short half-life and correspondingly large specific activity. On the ICP/MS, any mass observed at 242 is assumed to be Pu- 242 because of the longer half-life.

Table 4-10 (for LAW) and Table 4-11 (for HLW) provide minimum reportable quantities (MRQ) for the analytes in this DQO. These values are a guide for determining the required analytical sensitivity for reporting results in support of this DQO and were obtained from the LAW Feed DQO (Wiemers and Miller 1997) and the HLW Feed DQO (Wiemers et al. 1998). These levels provide efficient laboratory operation. Lower MRQ values may be achieved; however, in some cases, this may require additional work by the laboratory at additional cost. The method used for calculating the MRQ values is presented in a letter from the laboratory (Esch 1997). The MRQs in Table 4-10 and Table 4-11, differ from a Practical Quantitation Limit, as it is typically defined, in that the reported MRQs take into account the typical preparation/dilution required for the type of matrices in question. The preparation/dilution is dependent on the amount of solids, the concentration of the highest analyte in a multianalyte method, the concentration of any interfering analytes and/or the dose rate of the samples.

Table 4-10. Minimum Reportable Quantities for LAW. (2 sheets)

\begin{tabular}{|c|c|c|}
\hline : Analvit: & Wimmun Reportable & Unis: \\
\hline $\mathrm{Al}$ & $3.60 \mathrm{E}+03$ & $\mu \mathrm{g} / \mathrm{mL}$ \\
\hline Alpha & $7.50 \mathrm{E}-02$ & $\mu \mathrm{Ci} / \mathrm{mL}$ \\
\hline${ }^{241} \mathrm{Am}$ & $3.00 \mathrm{E}-04$ & $\mu \mathrm{Ci} / \mathrm{mL}$ \\
\hline${ }^{243} \mathrm{Am} / \mathrm{Cm}$ & $3.20 \mathrm{E}-03$ & $\mu \mathrm{Ci} / \mathrm{mL}$ \\
\hline $\mathrm{Ba}$ & $2.60 \mathrm{E}+01$ & $\mu \mathrm{g} / \mathrm{mL}$ \\
\hline $\mathrm{Ca}$ & $1.20 \mathrm{E}+02$ & $\mu \mathrm{g} / \mathrm{mL}$ \\
\hline $\mathrm{Cd}$ & $3.20 \mathrm{E}+02$ & $\mu \mathrm{g} / \mathrm{mL}$ \\
\hline $\mathrm{Cl}^{-}$ & $9.20 \mathrm{E}+02$ & $\mu \mathrm{g} / \mathrm{mL}$ \\
\hline${ }^{243+244} \mathrm{Cm}$ & $5.00 \mathrm{E}-02$ & $\mu \mathrm{g} / \mathrm{mL}$ \\
\hline $\mathrm{Cr}$ & $2.50 \mathrm{E}+02$ & $\mu \mathrm{g} / \mathrm{mL}$ \\
\hline
\end{tabular}


HNF-1802 Rev. 0

Table 4-10. Minimum Reportable Quantities for LAW. (2 sheets)

\begin{tabular}{|c|c|c|}
\hline 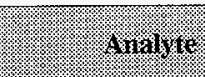 & Monmum Reprowant & Ining \\
\hline${ }^{137} \mathrm{Cs}$ & $8.20 \mathrm{E}+01$ & $\mu \mathrm{Ci} / \mathrm{mL}$ \\
\hline $\mathrm{F}$ & $1.20 \mathrm{E}+03$ & $\mu \mathrm{g} / \mathrm{mL}$ \\
\hline $\mathrm{Fe}$ & $3.90 \mathrm{E}+02$ & $\mu \mathrm{g} / \mathrm{mL}$ \\
\hline${ }^{3} \mathrm{H}$ & to be determined & \\
\hline $\mathrm{Hg}$ & $2.00 \mathrm{E}+00$ & $\mu \mathrm{g} / \mathrm{mL}$ \\
\hline $\mathrm{K}$ & $4.90 \mathrm{E}+03$ & $\mu \mathrm{g} / \mathrm{mL}$ \\
\hline $\mathrm{La}$ & $3.00 \mathrm{E}+01$ & $\mu \mathrm{g} / \mathrm{mL}$ \\
\hline $\mathrm{Na}$ & $1.60 \mathrm{E}+04$ & $\mu \mathrm{g} / \mathrm{mL}$ \\
\hline $\mathrm{Ni}$ & $1.20 \mathrm{E}+02$ & $\mu \mathrm{g} / \mathrm{mL}$ \\
\hline $\mathrm{NO}_{2}^{-}$ & $1.20 \mathrm{E}+04$ & $\mu \mathrm{g} / \mathrm{mL}$ \\
\hline $\mathrm{NO}_{3}{ }^{-}$ & $3.50 \mathrm{E}+04$ & $\mu \mathrm{g} / \mathrm{mL}$ \\
\hline${ }^{237} \mathrm{~Np}$ & $3.20 \mathrm{E}-03$ & $\mu \mathrm{Ci} / \mathrm{mL}$ \\
\hline $\mathrm{OH}^{-}$ & $2.50 \mathrm{E}+04$ & $\mu \mathrm{g} / \mathrm{mL}$ \\
\hline $\mathrm{Pb}$ & $9.90 \mathrm{E}+01$ & $\mu \mathrm{g} / \mathrm{mL}$ \\
\hline $\mathrm{PO}_{4}^{-}$ & $2.50 \mathrm{E}+03$ & $\mu \mathrm{g} / \mathrm{mL}$ \\
\hline${ }^{238} \mathrm{Pu}$ & $3.20 \mathrm{E}-03$ & $\mu \mathrm{Ci} / \mathrm{mL}$ \\
\hline${ }^{239} \mathrm{Pu}$ & $3.20 \mathrm{E}-03$ & $\mu \mathrm{Ci} / \mathrm{mL}$ \\
\hline${ }^{240} \mathrm{Pu}$ & $3.20 \mathrm{E}-03$ & $\mu \mathrm{Ci} / \mathrm{mL}$ \\
\hline${ }^{242} \mathrm{Pu}$ & $3.20 \mathrm{E}-03$ & $\mu \mathrm{Ci} / \mathrm{mL}$ \\
\hline${ }^{241} \mathrm{Pu} / \mathrm{Am}$ & $3.20 \mathrm{E}-03$ & $\mu \mathrm{Ci} / \mathrm{mL}$ \\
\hline${ }^{90} \mathrm{Sr}$ & $8.30 \mathrm{E}-01$ & $\mu \mathrm{Ci} / \mathrm{mL}$ \\
\hline $\mathrm{SO}_{4}^{-}$ & $7.70 \mathrm{E}+02$ & $\mu \mathrm{g} / \mathrm{mL}$ \\
\hline${ }^{99} \mathrm{Tc}$ & $8.50 \mathrm{E}-03$ & $\mu \mathrm{Ci} / \mathrm{mL}$ \\
\hline TIC & $2.50 \mathrm{E}+03$ & $\mu \mathrm{g} / \mathrm{mL}$ \\
\hline TOC & $5.00 \mathrm{E}+02$ & $\mu \mathrm{g} / \mathrm{mL}$ \\
\hline $\mathrm{U}$ & $2.60 \mathrm{E}+02$ & $\mu \mathrm{g} / \mathrm{mL}$ \\
\hline
\end{tabular}


HNF-1802 Rev. 0

Table 4-11. Minimum Reportable Quantities for HLW. (3 sheets)

\begin{tabular}{|c|c|c|}
\hline Amalite & 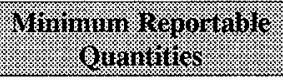 & Vins: \\
\hline $\mathrm{Ag}$ & $5.50 \mathrm{E}+00$ & $\mu \mathrm{g} / \mathrm{mL}$ \\
\hline $\mathrm{Al}$ & $3.60 \mathrm{E}+03$ & $\mu \mathrm{g} / \mathrm{mL}$ \\
\hline${ }^{241} \mathrm{Am}$ & $3.00 \mathrm{E}-04$ & $\mu \mathrm{Ci} / \mathrm{mL}$ \\
\hline As & $4.00 \mathrm{E}-01$ & $\mu \mathrm{g} / \mathrm{mL}$ \\
\hline $\mathrm{B}$ & $3.00 \mathrm{E}+01$ & $\mu \mathrm{g} / \mathrm{mL}$ \\
\hline $\mathrm{Ba}$ & $2.60 \mathrm{E}+01$ & $\mu \mathrm{g} / \mathrm{mL}$ \\
\hline $\mathrm{Be}$ & to be determined & \\
\hline $\mathrm{Bi}$ & $5.50 \mathrm{E}+01$ & $\mu \mathrm{g} / \mathrm{mL}$ \\
\hline${ }^{14} \mathrm{C}$ & $2.40 \mathrm{E}-04$ & $\mu \mathrm{Ci} / \mathrm{mL}$ \\
\hline $\mathrm{Ca}$ & $1.20 \mathrm{E}+02$ & $\mu \mathrm{g} / \mathrm{mL}$ \\
\hline $\mathrm{Cd}$ & $3.20 \mathrm{E}+02$ & $\mu \mathrm{g} / \mathrm{mL}$ \\
\hline $\mathrm{Ce}$ & $5.50 \mathrm{E}+01$ & $\mu \mathrm{g} / \mathrm{mL}$ \\
\hline $\mathrm{Cl}^{-}$ & $9.20 \mathrm{E}+02$ & $\mu \mathrm{g} / \mathrm{mL}$ \\
\hline${ }^{243+244} \mathrm{Cm}$ & $5.00 \mathrm{E}-02$ & $\mu \mathrm{g} / \mathrm{mL}$ \\
\hline $\mathrm{CN}^{-}$ & to be determined & \\
\hline Co & $1.00 \mathrm{E}-02$ & $\mu \mathrm{g} / \mathrm{mL}$ \\
\hline${ }^{60} \mathrm{Co}$ & $1.00 \mathrm{E}-02$ & $\mu \mathrm{Ci} / \mathrm{mL}$ \\
\hline $\mathrm{Cr}$ & $2.50 \mathrm{E}+02$ & $\mu \mathrm{g} / \mathrm{mL}$ \\
\hline $\mathrm{Cs}$ & $5.00 \mathrm{E}-01$ & $\mu \mathrm{g} / \mathrm{mL}$ \\
\hline${ }^{137} \mathrm{Cs}$ & $8.20 \mathrm{E}+01$ & $\mu \mathrm{Ci} / \mathrm{mL}$ \\
\hline $\mathrm{Cu}$ & $5.50 \mathrm{E}+00$ & $\mu \mathrm{g} / \mathrm{mL}$ \\
\hline${ }^{152 / 154 / 155} \mathrm{Eu}$ & $1.00 \mathrm{E}-02$ & $\mu \mathrm{Ci} / \mathrm{mL}$ \\
\hline $\mathrm{F}^{-}$ & $1.20 \mathrm{E}+03$ & $\mu \mathrm{g} / \mathrm{mL}$ \\
\hline $\mathrm{Fe}$ & $3.90 \mathrm{E}+02$ & $\mu \mathrm{g} / \mathrm{mL}$ \\
\hline${ }^{3} \mathrm{H}$ & $7.00 \mathrm{E}-03$ & $\mu \mathrm{Ci} / \mathrm{mL}$ \\
\hline $\mathrm{Hg}$ & $2.00 \mathrm{E}+00$ & $\mu \mathrm{g} / \mathrm{mL}$ \\
\hline${ }^{129} I$ & $5.80 \mathrm{E}-06$ & $\mu \mathrm{Ci} / \mathrm{mL}$ \\
\hline $\mathrm{K}$ & $4.90 \mathrm{E}+03$ & $\mu \mathrm{g} / \mathrm{mL}$ \\
\hline $\mathrm{La}$ & $3.00 \mathrm{E}+01$ & $\mu \mathrm{g} / \mathrm{mL}$ \\
\hline $\mathrm{Li}$ & $5.50 \mathrm{E}+00$ & $\mu \mathrm{g} / \mathrm{mL}$ \\
\hline $\mathrm{Mg}$ & $5.40 \mathrm{E}+03$ & $\mu \mathrm{g} / \mathrm{mL}$ \\
\hline $\mathrm{Mn}$ & $5.50 \mathrm{E}+00$ & $\mu \mathrm{g} / \mathrm{mL}$ \\
\hline Mo & $3.00 \mathrm{E}+01$ & $\mu \mathrm{g} / \mathrm{mL}$ \\
\hline
\end{tabular}


HNF-1802 Rev. 0

Table 4-11. Minimum Reportable Quantities for HLW. (3 sheets)

\begin{tabular}{|c|c|c|}
\hline Arative: & $\begin{array}{l}\text { Menmun Reportatil } \\
\text { Orantines }\end{array}$ & Unts: \\
\hline $\mathrm{Na}$ & $1.60 \mathrm{E}+04$ & $\mu \mathrm{g} / \mathrm{mL}$ \\
\hline $\mathrm{Nd}$ & $5.50 \mathrm{E}+01$ & $\mu \mathrm{g} / \mathrm{mL}$ \\
\hline $\mathrm{NH}_{3} / \mathrm{NH}_{4}{ }^{+}$ & $4.50 \mathrm{E}+01$ & $\mu \mathrm{g} / \mathrm{mL}$ \\
\hline $\mathrm{Ni}$ & $1.20 \mathrm{E}+02$ & $\mu \mathrm{g} / \mathrm{mL}$ \\
\hline $\mathrm{NO}_{2}^{-}$ & $1.20 \mathrm{E}+04$ & $\mu \mathrm{g} / \mathrm{mL}$ \\
\hline $\mathrm{NO}_{3}^{-}$ & $3.50 \mathrm{E}+04$ & $\mu \mathrm{g} / \mathrm{mL}$ \\
\hline $\mathrm{OH}^{-}$ & $2.50 \mathrm{E}+04$ & $\mu \mathrm{g} / \mathrm{mL}$ \\
\hline $\mathbf{P}$ & $1.10 \mathrm{E}+02$ & $\mu \mathrm{g} / \mathrm{mL}$ \\
\hline $\mathrm{Pb}$ & $9.90 \mathrm{E}+01$ & $\mu \mathrm{g} / \mathrm{mL}$ \\
\hline $\mathrm{Pd}$ & to be determined & \\
\hline $\mathrm{Pm}$ & to be determined & \\
\hline $\operatorname{Pr}$ & $6.00 \mathrm{E}+00$ & $\mu \mathrm{g} / \mathrm{mL}$ \\
\hline${ }^{238} \mathrm{Pu}$ & $3.20 \mathrm{E}-03$ & $\mu \mathrm{Ci} / \mathrm{mL}$ \\
\hline${ }^{239} \mathrm{Pu}$ & $3.20 \mathrm{E}-03$ & $\mu \mathrm{Ci} / \mathrm{mL}$ \\
\hline${ }^{241} \mathrm{Pu}$ & $3.20 \mathrm{E}-03$ & $\mu \mathrm{Ci} / \mathrm{mL}$ \\
\hline$S$ & $5.50 \mathrm{E}+01$ & $\mu \mathrm{g} / \mathrm{mL}$ \\
\hline $\mathrm{Sb}$ & $3.50 \mathrm{E}+01$ & $\mu \mathrm{g} / \mathrm{mL}$ \\
\hline $\mathrm{Se}$ & $5.50 \mathrm{E}+01$ & $\mu \mathrm{g} / \mathrm{mL}$ \\
\hline $\mathrm{Si}$ & $3.00 \mathrm{E}+01$ & $\mu \mathrm{g} / \mathrm{mL}$ \\
\hline${ }^{126} \mathrm{Sn}$ & $2.00 \mathrm{E}-03$ & $\mu \mathrm{Ci} / \mathrm{mL}$ \\
\hline${ }^{90} \mathrm{Sr}$ & $8.30 \mathrm{E}-01$ & $\mu \mathrm{Ci} / \mathrm{mL}$ \\
\hline $\mathrm{Ta}$ & to be determined & \\
\hline $\mathrm{Te}$ & $1.80 \mathrm{E}+01$ & $\mu \mathrm{g} / \mathrm{mL}$ \\
\hline${ }^{99} \mathrm{Tc}$ & $8.50 \mathrm{E}-03$ & $\mu \mathrm{Ci} / \mathrm{mL}$ \\
\hline Th & $6.00 \mathrm{E}+00$ & $\mu \mathrm{g} / \mathrm{mL}$ \\
\hline $\mathrm{Ti}$ & $5.50 \mathrm{E}+00$ & $\mu \mathrm{g} / \mathrm{mL}$ \\
\hline TIC & $2.50 \mathrm{E}+03$ & $\mu \mathrm{g} / \mathrm{mL}$ \\
\hline $\mathrm{Tl}$ & to be determined & \\
\hline TOC & $5.00 \mathrm{E}+02$ & $\mu \mathrm{g} / \mathrm{mL}$ \\
\hline $\mathrm{U}$ & $2.60 \mathrm{E}+02$ & $\mu \mathrm{g} / \mathrm{mL}$ \\
\hline${ }^{233} \mathrm{U}$ & $6.00 \mathrm{E}-04$ & $\mu \mathrm{Ci} / \mathrm{mL}$ \\
\hline${ }^{235} \mathrm{U}$ & $1.08 \mathrm{E}-06$ & $\mu \mathrm{Ci} / \mathrm{mL}$ \\
\hline $\mathrm{V}$ & $3.00 \mathrm{E}+01$ & $\mu \mathrm{g} / \mathrm{mL}$ \\
\hline W & $6.00 \mathrm{E}+00$ & $\mu \mathrm{g} / \mathrm{mL}$ \\
\hline
\end{tabular}


Table 4-11. Minimum Reportable Quantities for HLW. (3 sheets)

\begin{tabular}{|c|c|c|}
\hline - Aratrof & $\begin{array}{l}\text { Mrinumin Reportable } \\
\text { Orantitres }\end{array}$ & Im \\
\hline $\mathrm{Y}$ & to be determined & \\
\hline $\mathrm{Zn}$ & $5.50 \mathrm{E}+00$ & $\mu \mathrm{g} / \mathrm{mL}$ \\
\hline $\mathrm{Zr}$ & $5.50 \mathrm{E}+00$ & $\mu \mathrm{g} / \mathrm{mL}$ \\
\hline
\end{tabular}

\subsection{DEFINE THE STUDY BOUNDARIES}

This DQO is applicable when a proposed waste transfer affects one of the static Phase 1 tanks. This occurs anytime waste is transferred (except when transferred into the staging tank) into or out of a Phase 1 tank listed in Tables 2-1 or 2-2. This DQO will be in place until the waste in each tank listed in Tables 2-1 or 2-2 is retrieved for treatment and disposal or this DQO is superseded by other documentation.

\subsection{DECISION RULES}

Decision rules define how to evaluate results and actions required as a result of exceeding an action level.

For the low activity waste (Envelopes A, B, and C), the action levels are $>80 \%$ of the maximum ratio, analyte (mole) to sodium (mole) shown in Table $4-3$, and $>80 \%$ of the maximum ratio, radionuclide $(\mathrm{Bq})$ to sodium (mole) shown in Table 4-4. The action limit for the quantity of solids in a waste transfer is $>5$ volume percent. The action limits for sodium concentration for the quantity of waste feed is $20 \%$ above the lower limit $(3 \mathrm{M})$ and $20 \%$ below the upper limit (14 M). The action level for Total Alpha is the action level for the TRU shown in Table 4-4. The action levels for the operating specifications from OSD-T-151-00007, Revision H-16 (PHMC 1997) are the limits shown in Table 4-8. The action is taken if the simple mean of the analyses obtained is above or below the limits shown in Table 4-8.

For the high level waste (Envelope D), the action levels are $>80 \%$ of the maximum allowable element content shown in Tables 4-5, 4-6, and 4-7.

The following decision rules cover the questions shown in Section 3.0 and the decision points shown in the logic diagram (Section 3.0).

- If the required data (see: Tables 4-3, 4-4, 4-5, 4-6, 4-7, and 4-8, sodium quantity, and the solids quantity) meet the action level requirements for each analyte or parameter (see above), then the waste may be transferred. 
The decision rule above is true for mixing Envelope B waste with Envelope B waste and mixing Envelope $C$ waste with Envelope $C$ waste only if the identity of the discriminating analytes (the analytes that cause a specific batch of waste to be categorized as Envelope B or C) are the same. If the discriminating analytes are different, then the transfer decision is made by WIC. The potential discriminating analytes for Envelope B waste are $\mathrm{Cl}, \mathrm{Cr}, \mathrm{F}, \mathrm{PO}_{4}$, and $\mathrm{SO}_{4}$; the potential discriminating analytes for Envelope $\mathrm{C}$ waste are ${ }^{90} \mathrm{Sr}$ and TRU (see Tables 4-3 and 4-4).

- If any the required data inputs fails to meet the action level requirements or if the discriminating analytes are different in incoming Envelope $\mathrm{B}$ or $\mathrm{C}$ waste, then the decision to transfer waste into a Phase 1 tank is made by WIC after evaluating the effect a transfer would have on the waste presently in the tank.

- If any transfer out of a Phase 1 tank is planned, then the decision to make that transfer is made by WIC after evaluating the affect a transfer would have on the waste remaining in the tank in terms of composition, quantity, or timing.

The requirements for the decisions on waste transfers into or out of a tank made by WIC is not presented here because each case can be different. The transfer decisions made by WIC are made from information that could change for any specific transfer, such as the quantity of waste to be transferred, which element and the amount over the action level, and the contents of the tank.

\subsection{SPECIFY LIMITS ON DECISION ERROR}

The limits for Envelopes A, B, and C are given in terms of the ratio of moles analyte to mole sodium or Becquerel $(\mathrm{Bq})$ per mole sodium. To form the ratio from the analytical results from the supernate samples, $\mu \mathrm{g} / \mathrm{mL}$ and $\mu \mathrm{Ci} / \mathrm{mL}$ are converted to moles $/ \mathrm{mL}$ and $\mathrm{Bq} / \mathrm{mL}$. Each mean analyte concentration is divided by the mean sodium concentration. These ratios of means are given in Equations 1 and 2.

$$
\begin{aligned}
& \text { Ratio }=\frac{\text { Mean analyte concentration }(\mathrm{moles} / \mathrm{mL})}{\text { Mean sodium concentration (moles } / \mathrm{mL})} \\
& \text { Ratio }=\frac{\text { Mean analyte concentration }(\mathrm{Bq} / \mathrm{mL})}{\text { Mean sodium concentration (moles } / \mathrm{mL})}
\end{aligned}
$$


The variance of a ratio is needed to compute a confidence interval (CI) on the ratio. An approximation to the variance of a ratio will be used. If the numerator and denominator of the ratio are independent then,

$$
\begin{gathered}
\operatorname{RSD}^{2}\left(\frac{X}{Y}\right) \approx \operatorname{RSD}^{2}(X)+\operatorname{RSD}^{2}(Y) \\
\text { where } \operatorname{RSD}(X)=\frac{\sigma(X)}{\mu(X)} \text { and } \operatorname{RSD}(\mathrm{Y})=\frac{\sigma(\mathrm{Y})}{\mu(\mathrm{Y})},
\end{gathered}
$$

$\sigma$ is a standard deviation, $\mu$ is the mean, and RSD is a relative standard deviation. The estimate of the RSD is obtained by replacing $\mu$ and $\sigma$ by their estimates. The variance of the ratio (Equation 3) is approximate, the adequacy of the approximation is not known.

The upper limit (UL)(95\%, Ratio) to a one-sided 95\% CI for the ratio R (Equations 1 and 2) is approximately

$$
\mathrm{UL}(95 \%, \text { Ratio })=\hat{R}+t_{(\mathrm{dr}, 0.05)} \times \hat{\sigma}(\hat{R}),
$$

where $\hat{\mathrm{R}}$ is the ratio of means, $\mathrm{t}_{(\mathrm{dr}, 0.05)}$ is the quantile from Student's $t$ distribution with $d f$ degrees of freedom for a one-sided $95 \% \mathrm{CI}$ and $\hat{\sigma}(\hat{\mathrm{R}})$ is the estimate of the standard deviation of the ratio (Equation 3). The $d f$ are approximate, they are the smaller of the $d f$ for the estimate of the variance of the numerator or of the denominator.

For each analyte, the UL (Equation 4) to a $95 \% \mathrm{CI}$ for a ratio is compared to $80 \%$ of the envelope limit. If UL is less than $80 \%$ of the envelope limit, then the analyte satisfies the test criteria. The comparison using UL incorporates spatial and measurement variability in the data.

For Total Alpha, the action limit is the envelope limit (not $80 \%$ of the envelope limit as with the other analytes). Therefore, the $95 \% \mathrm{CI}$ is compared to the actual limit for TRU (see Table 4-4).

For the sodium concentration limits $(3 \mathrm{M} \leq[\mathrm{Na}] \leq 14 \mathrm{M})$, a two-sided $95 \%$ CI will be used.

For the data requirements from OSD-T-151-00007, Rev. H-16 (PHMC 1997) (Table 4-8), the test to determine if the action levels are met is a simple mean of the data analyses.

The limits for Envelope $\mathrm{D}$ are given in terms of the concentration of each analyte. In this case, the UL( $95 \%)$ to a one-sided $95 \% \mathrm{CI}$ for the mean $\mu$ (Equations 1 and 2 ) equals

$$
\mathrm{UL}(95 \%)=\hat{\mu}+\mathrm{t}_{(\mathrm{df}, 0.05)} \times \hat{\sigma}(\hat{\mu})
$$


where $\hat{\mu}$ is the mean estimate, $\mathbf{t}_{(\mathrm{df}, 0.05)}$ is the quantile from Student's $\mathbf{t}$ distribution with $d f$ degrees of freedom for a one-sided $95 \% \mathrm{CI}$, and $\hat{\sigma}(\hat{\mu})$ is the estimate of the standard deviation of the mean.

For each analyte, the UL (Equation 5) to a $95 \% \mathrm{CI}$ is compared to $80 \%$ of the envelope limit. If UL is less than $80 \%$ of the envelope limit, then the analyte satisfies the test criteria. The comparison using $\mathrm{UL}$ incorporates spatial and measurement variability in the data.

Any time the UL of one or more analytes is greater than the action level, the transfer decision is made by WIC.

\subsection{OPTIMIZE THE DESIGN FOR OBTAINING DATA}

A minimum of two samples and analyses is required to determine an UL to a $95 \% \mathrm{CI}$ for any particular analyte. Therefore, a minimum of two samples is required for this DQO.

However, if a significant amount (greater than 20,000 gallons) of waste is being transferred within the double shell tank system, the number of samples will be reviewed at the time of the proposed transfer and additional samples may be required if WIC believes the waste is not well mixed. 


\subsection{REFERENCES}

Boston, H. L., 1996, Feed Process Management Control Team, (Internal Memorandum DPO-96-092 to L. Hall), Lockheed Martin Hanford Corporation, Richland, Washington.

DOE-RL, 1996, TWRS Privatization (BNFL \& LM), Contracts DE-RP06-96L13308 and DE-RP06-96L13309, September, U.S. Department of Energy, Richland Operations Office, Richland, Washington.

Esch, R. A., 1997, Minimum Reportable Quantities for Low-Activity Privatization Data Quality Objective, (Letter, WMH-9759641 to K. D. Wiemers, October 1997), Waste Management Federal Services of Hanford, Inc., Richland, Washington.

Fowler, K. D., 1995, Tank Farm Waste Transfer Compatibility Program, WHC-SD-WM-OCD-015, Rev. 1, Westinghouse Hanford Company, Richland, Washington.

LMHC, 1997, TWRS Administrative Manual, HNF-IP-0842, Volume I, Section 3.12, Revision 2, titled DST Waste Inventory Control Charter, Lockheed Martin Hanford Corporation, Richland, Washington.

Mulkey, C. H., and M. S. Miller, 1997, Data Quality Objectives for Tank Farms Waste Compatibility Program, HNF-SD-WM-DQO-001, Rev. 2, Lockheed Martin Hanford Corporation for Fluor Daniel Hanford, Inc., Richland, Washington.

PHMC, 1997, Unclassified Operating Specification for the 241-AN, AP, $A W, A Y, A Z$, and $S Y$, OSD-T-151-00007, Revision H-16, Fluor Daniel Hanford, Richland Washington.

Wicks, J. H., 1997, Subcontract Number 80232764-9-K001, Configuration Control of Tank Waste Composition, (Letter, LMHC-9755448 to W. M. Funderburk, June 20), Lockheed Martin Hanford Corporation, Richland, Washington.

Wiemers, K. D. and Miller, M. S., 1997, Low-Activity Waste Feed Data Quality Objectives, WIT-98-010, Rev. 0, Pacific Northwest National Laboratory, Richland, Washington.

Wiemers, K. D., Patello, G. K., and Miller, M. S., 1998, High-Level Waste Feed Data Quality Objectives, WIT-98-024, Rev. 0, Pacific Northwest National Laboratory, Richland, Washington. 
HNF-1802 Rev, 0

This page intentionally left blank. 


\begin{tabular}{|c|c|c|c|c|c|}
\hline \multirow[b]{2}{*}{ Distribution } & \multirow{2}{*}{\multicolumn{3}{|c|}{$\begin{array}{l}\text { From } \\
\text { Technical Basis and Planning }\end{array}$}} & \multicolumn{2}{|l|}{ Page 1 of 2} \\
\hline & & & & \multicolumn{2}{|c|}{$07 / 30 / 98$} \\
\hline \multicolumn{4}{|l|}{ Project Title/Work Order } & \multicolumn{2}{|c|}{ EDT No. $\quad$ EDT-622458 } \\
\hline \multicolumn{4}{|c|}{$\begin{array}{l}\text { HNF-1802, Rev. 0, "Data Quality Objectives for TWRS } \\
\text { Privatization Phase 1: Tank Waste Transfer Control" }\end{array}$} & \multicolumn{2}{|c|}{ ECN No. $N / A$} \\
\hline Name & MSIN & $\begin{array}{c}\text { Text } \\
\text { With All } \\
\text { Attach. }\end{array}$ & Text Only & $\begin{array}{l}\text { Attach./ } \\
\text { Appendix } \\
\text { Only }\end{array}$ & $\begin{array}{l}\text { EDT/ECN } \\
\text { Only }\end{array}$ \\
\hline
\end{tabular}

\section{ONSITE}

Department of Energy - RL Operations

N. R. Brown

N. C. Welliver

DE\&S Hanford. Inc.

C. E. Leach

R1 -49

A $0-21$

$\mathrm{A} 0-21$

$X$
$X$

Lockheed Martin Hanford, Corp.

J. H. Baldwin

D. L. Banning

T. M. Blaak

J. F. Bores

H. L. Boston

V. C. Boyles

T. W. Crawford

R. A. Dodd

K. D. Fowler

K. M. Hall

J. W. Hunt

J. Jo

N. W. Kirch

J. G. Kristofzski

C. H. Mulkey

R. J. Murkowski

L. D. Pennington

R. W. Powe11

T.C.S.R.C.

Lockheed Martin Services, Inc.

Central Files

MACTEC

S. M. Blacker

M. J. O'Neill

R. L. Treat

Numatec Hanford Corp.

P. J. Certa

R. D. Claghorn

J. S. Garfield

D. L. Herting

R. P. Marsha7 1
H5-03

R2-12

S5-13

G3-21

G3-21

R2-11

H5- 49

S5-07

R2-11

R2-12

R2-12

R2-12

R2-11

R2-12

R1-51

H6-37

S7-21

H5-03

R1-10

B1-07

$x$
$x$
$x$
$x$
$x$
$x$
$x$
$x$
$x$
$x$
$x$
$x$
$x$
$x$
$x$
$x$
$x$
$x$
$x$

H5- 49

G3-21

H5- 03

$x$
$x$
$x$

H5-61

H5- 49

H5-49

T6-07

H5-61
$X$

$x$
$x$
$x$
$x$
$x$
$x$
$x$
$x$
$x$
$x$
$x$
$x$
$x$
$x$
$x$
$x$
$x$




\begin{tabular}{|c|c|c|c|c|c|}
\hline \multirow{2}{*}{$\begin{array}{l}\text { To } \\
\quad \text { Distribution }\end{array}$} & \multirow{2}{*}{\multicolumn{3}{|c|}{$\begin{array}{l}\text { From } \\
\text { Technical Basis and Planning }\end{array}$}} & \multicolumn{2}{|l|}{ Page 2 of 2} \\
\hline & & & & \multicolumn{2}{|c|}{ Date $\quad 07 / 30 / 98$} \\
\hline \multicolumn{4}{|l|}{ Project Title/Work Order } & \multicolumn{2}{|c|}{ EDT No. EDT-622458 } \\
\hline \multicolumn{4}{|c|}{$\begin{array}{l}\text { HNF-1802, Rev. 0, "Data Quality Objectives for TWRS } \\
\text { Privatization Phase 1: Tank Waste Transfer Control" }\end{array}$} & \multicolumn{2}{|l|}{ ECN No. N/A } \\
\hline Name & MSIN & $\begin{array}{l}\text { Text } \\
\text { With All } \\
\text { Attach. }\end{array}$ & Text Only & $\begin{array}{l}\text { Attach./ } \\
\text { Appendix } \\
\text { Only }\end{array}$ & $\begin{array}{l}\text { EDT/ECN } \\
\text { Only }\end{array}$ \\
\hline
\end{tabular}

Numatec Hanford Corp. - continued

R. M. Orme

H5-27

I. G. Papp

H5- 49

W. I. Winters

T6-50

$x$
$x$
$x$

